\title{
Preparation and characterization of an anti-inflammatory agent based on a zinc-layered hydroxide-salicylate nanohybrid and its effect on viability of Vero-3 cells
}

\author{
This article was published in the following Dove Press journal: \\ International Journal of Nanomedicine \\ 15 January 2013 \\ Number of times this article has been viewed
}

\author{
Munirah Ramli ${ }^{1,2}$ \\ Mohd Zobir Hussein ${ }^{1,3}$ \\ Khatijah Yusoff ${ }^{4}$ \\ 'Advanced Materials and \\ Nanotechnology Laboratory, \\ Institute of Advanced Technology, \\ Universiti Putra Malaysia, Serdang, \\ Selangor, ${ }^{2}$ Department of Industrial \\ Biotechnology, Faculty of Biosciences \\ and Bioengineering, Universiti \\ Teknologi Malaysia, Skudai, Johor, \\ ${ }^{3}$ Department of Chemistry, Faculty \\ of Science, Universiti Putra Malaysia, \\ Serdang, Selangor, ${ }^{4}$ Department \\ of Microbiology, Faculty of \\ Biotechnology and Biomolecular \\ Sciences, Universiti Putra Malaysia, \\ Serdang, Selangor, Malaysia
}

\begin{abstract}
A new organic-inorganic nanohybrid based on zinc-layered hydroxide intercalated with an anti-inflammatory agent was synthesized through direct reaction of salicylic acid at various concentrations with commercially available zinc oxide. The basal spacing of the pure phase nanohybrid was $15.73 \AA$, with the salicylate anions arranged in a monolayer form and an angle of 57 degrees between the zinc-layered hydroxide interlayers. Fourier transform infrared study further confirmed intercalation of salicylate into the interlayers of zinc-layered hydroxide. The loading of salicylate in the nanohybrid was estimated to be around $29.66 \%$, and the nanohybrid exhibited the properties of a mesoporous-type material, with greatly enhanced thermal stability of the salicylate compared with its free counterpart. In vitro cytotoxicity assay revealed that free salicylic acid, pure zinc oxide, and the nanohybrid have a mild effect on viability of African green monkey kidney (Vero-3) cells.
\end{abstract}

Keywords: anti-inflammatory, salicylic acid, zinc-layered hydroxide, zinc oxide, nanohybrid, cytotoxicity

\section{Introduction}

Development of drug delivery systems that can effectively elicit the intended therapeutic effect in patients with minimal adverse reactions has been widely explored in recent years. This research was mainly catalyzed by the challenges in attaining satisfactory pharmacokinetic profiles using conventional drug administration methods. ${ }^{1}$ The emergence of nanomedicine, a convergence between nanoscience and medicine, has markedly potentiated the revolution in delivery of therapeutic compounds through fabrication of ingenious nanovehicles. ${ }^{2-6}$

Application of inorganic nanoparticles in drug delivery systems has garnered considerable attention because they possess versatile attributes, including wide availability, good biocompatibility, and rich surface functionality. ${ }^{4}$ Targeted delivery of a drug molecule to the desired site of action is also made achievable by use of nanoparticles as carriers, which has been found to be exceptionally beneficial in studies involving delivery of chemotherapeutic agents in cancer therapy. ${ }^{7}$ In addition, nanoparticle-based drug delivery systems can slowly release the carried drugs in order to maintain concentrations at the desired levels for an extended period of time. ${ }^{8}$ To date, a multitude of inorganic nanoparticles has been extensively employed in drug delivery studies, including iron oxide,,${ }^{9,10}$ silica nanoparticles, ${ }^{11}$ calcium phosphate or hydroxyapatite,${ }^{12,13}$ 
gold nanoparticles, ${ }^{14}$ carbon nanotubes, ${ }^{15}$ dendrimers, ${ }^{16}$ layered double hydroxides, ${ }^{17-19}$ and quantum dots. ${ }^{20,21}$

Layered double hydroxides (LDHs) are regarded as promising drug delivery carriers because of several notable characteristics. In addition to ease of laboratory preparation and precise tailoring for the required physical and chemical properties, ${ }^{4}$ LDHs can be versatile carriers because various drugs can be intercalated into the interlayer spacing through ion exchange, and their degradation in an acidic cellular environment liberates the carried drugs in their ionic form, which helps improve their solubility and bioavailability. ${ }^{22}$ Improved cellular uptake of the drug-LDH nanohybrid has been reported, ${ }^{23}$ possibly because of its high zeta potential that provides a strong driving force to the surface of a cell. ${ }^{24}$ LDHs are also excellent candidates for drug delivery systems because they possess good biocompatibility and low cytotoxicity. ${ }^{25-27}$

LDHs are hydrotalcite-like materials that can be readily synthesized through introduction of base to a suitable mixture of metal salts. ${ }^{28}$ The structure of the LDH is based on individual layers of metal cations octahedrally arranged with hydroxide groups, in which each hydroxide is surrounded by three metal cations, creating neutral layers. Isomorphic replacement of divalent cations with trivalent cations creates an excess of charge in the layers, which is neutralized by the interlayer anions. It can be represented by the general hydrotalcite formula, $\left.\left[\mathrm{M}^{2+}{ }_{1-x} \mathrm{M}^{3+}{ }_{x}(\mathrm{OH})_{2}\right]^{x+}\left(\mathrm{A}^{m-}\right)_{x / m}\right] \cdot n \mathrm{H}_{2} \mathrm{O}$, where $\mathrm{M}^{2+}$ is divalent cations, $\mathrm{M}^{3+}$ is trivalent cations, and $\mathrm{A}^{m-}$ is an exchangeable anion with an $m$ - charge. ${ }^{29}$ Zinclayered hydroxide (ZLH) is another type of material made up of brucite-like layers. The layers are modified such that one quarter of the octahedral sites are vacant. Tetrahedrally coordinated zinc cations are located at the up and down side of the vacant octahedra, while the tetrahedra are formed by three hydroxide groups of the brucite-like layers and a water molecule. ${ }^{30,31}$ The structure can be represented by the general formula $\mathrm{M}^{2+}(\mathrm{OH})_{2-x}\left(\mathrm{~A}^{m-}\right)_{x / m} \cdot n \mathrm{H}_{2} \mathrm{O}$, where $\mathrm{M}^{2+}$ is the $\mathrm{Zn}^{2+}$ and $\mathrm{A}^{m-}$ is the counter anion with an $m-$ charge. ${ }^{32}$

Similar to LDH, the use of ZLH as a potential delivery vector is currently being studied extensively. Many successful intercalations have been reported with various therapeutic compounds, including conjugated linoleic acid, ${ }^{33}$ indole-3acetic acid, ${ }^{34}$ gallic acid,,$^{35}$ ascorbic acid, retinoic acid, and $\alpha$-tocopherol. ${ }^{36}$

Salicylic acid, also known as 2-hydroxybenzoic acid, is a nonsteroidal anti-inflammatory agent commonly used in the treatment of arthritis. Its use is often associated with adverse effects, including formation of gastric and duodenal ulcers, ${ }^{37}$ so developing a carrier that might alleviate such effects is desirable. Intercalation of salicylate into different LDH has previously been reported, ${ }^{38-40}$ but no report on the use of ZLH as the carrier could be found in the literature. In addition, very little information is available on the use of zinc oxide $(\mathrm{ZnO})$ as the starting material for synthesis of a drug-intercalated nanohybrid..$^{24,41}$ Therefore, to illustrate the use of $\mathrm{ZnO}$ for intercalation of organic compounds with therapeutic effects, this study focused on the formation of a nanohybrid compound consisting of an anti-inflammatory active agent, salicylate, and using $\mathrm{ZnO}$ as the starting material. The synthesized nanohybrid was later subjected to a cytotoxicity study using in vitro cells.

\section{Materials and methods Materials}

Salicylic acid (98\% purity) was purchased from $\mathrm{HmbG}$ Chemicals (Hamburg, Germany) and used as received. $\mathrm{ZnO}$ of American Chemical Society Standard reagent grade was purchased from Acros Organics (Geel, Belgium) and used without further purification. Deionized water and ethanol were used in all experiments. Dulbecco's modified Eagle's medium was purchased from PAA Laboratories (Pasching, Austria), and 3-(4,5-dimethylthiazol-2-yl)-2,5-diphenyltetrasodium bromide (MTT) from Invitrogen (Carlsbad, CA), and used as received. Dimethylsulfoxide of tissue culture grade was purchased from Sigma-Aldrich (St Louis, MO) and used without further purification.

\section{Preparation of salicylate nanohybrids}

Salicylate-zinc layered hydroxide nanohybrids (SZNs) were synthesized using $\mathrm{ZnO}$ as the starting material by a direct method reported previously. ${ }^{24}$ Salicylic acid solution (0.1$1.6 \mathrm{~mol} / \mathrm{L}$ ) was prepared by dissolving the appropriate amount of salicylic acid in ethanol, followed by stirring at ambient temperature for 10 minutes. $\mathrm{ZnO}(0.2 \mathrm{~g})$ was mixed with the solution of salicylic acid and stirred vigorously until the solution became clear. The $\mathrm{pH}$ was adjusted to $8.0 \mathrm{using}$ an aqueous solution of $\mathrm{NaOH}(1.0 \mathrm{~mol} / \mathrm{L})$ and vigorously stirred further for 4 hours at ambient temperature. The resulting white precipitate was matured at $70^{\circ} \mathrm{C}$ in an oil bath shaker for 18 hours. The precipitate was centrifuged and washed thoroughly with deionized water and dried in an oven at $60^{\circ} \mathrm{C}$. The powdered material was stored in a sample bottle placed in a container with desiccant for further use and characterization.

\section{Characterization}

Powder X-ray diffraction patterns were recorded at 2-60 degrees on a diffractometer (XRD-6000, Shimadzu, 
Tokyo, Japan) using $\mathrm{CuK}_{\alpha}$ radiation at $40 \mathrm{kV}$ and $30 \mathrm{~mA}$. Fourier transform infrared (FTIR) spectra of the materials were recorded over the range of $400-4000 \mathrm{~cm}^{-1}$ on an FTIR spectrophotometer (1725X, Perkin-Elmer, Waltham, MA) using a $\mathrm{KBr}$ disc method. Analysis of carbon, hydrogen, nitrogen, and sulfur (CHNS) content in the materials was performed using a Leco model CHNS-932 analyzer (St Joseph, MI), while elemental analysis was performed using inductively-coupled plasma atomic emission spectroscopy (Optima 2000DV, Perkin-Elmer). Thermogravimetric and differential thermogravimetric analysis (TGA-DTG) was carried out using a thermogravimetric analyzer (Mettler Toledo, Greifensee,
Switzerland). Surface characterization of the materials was done using a nitrogen gas adsorption-desorption technique at $77 \mathrm{~K}$ (ASAP 2000, Micromeritics, Norcross, GA). The surface morphology of the materials was observed using a field emission scanning electron microscope (Nova NanoSEM 230, Hillsboro, OR).

\section{MTT cytotoxicity assay}

The cytotoxicity of the synthesized material was determined using the MTT assay. African green monkey kidney (Vero-3) cells were grown in Dulbecco's modified Eagle medium supplemented with $10 \%$ fetal bovine serum at $37^{\circ} \mathrm{C}$ with $5 \% \mathrm{CO}_{2}$.

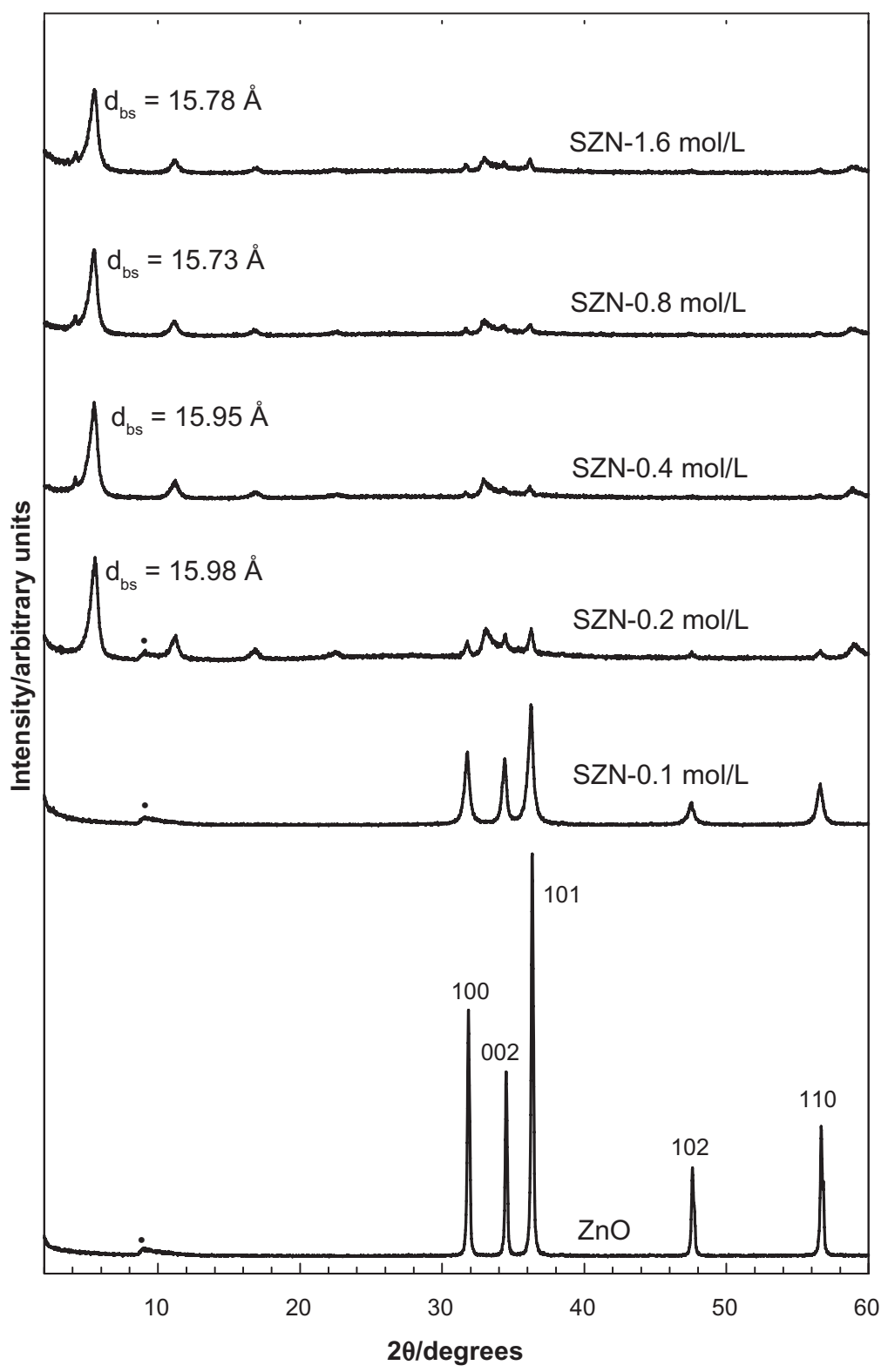

Figure I Powder X-ray diffraction patterns for zinc oxide and SZN prepared at various concentrations of salicylic acid. Note: (.) indicates unknown peak generated by the diffractometer. Abbreviation: SZN, salicylate-zinc layered hydroxide nanohybrid. 
The cells $\left(5 \times 10^{4}\right.$ cells $\left./ \mathrm{mL}\right)$ were seeded into a 96 -well plate and incubated for 24 hours at $37^{\circ} \mathrm{C}$ with $5 \% \mathrm{CO}_{2}$. Test samples were diluted in Dulbecco's modified Eagle's medium and $200 \mu \mathrm{L}$ was added into each well. After 48 hours of incubation, MTT reagent $(0.5 \mathrm{mg} / \mathrm{mL})$ in phosphate-buffered saline was added into each well and incubated further for 4 hours at $37^{\circ} \mathrm{C}$. The MTT solution was removed, and $100 \mu \mathrm{L}$ of dimethylsulfoxide was added into each well in order to dissolve formazan crystals. The plate was then analyzed under a microtiter plate reader at $570 \mathrm{~nm}$.

\section{Results and discussion $X$-ray diffraction}

Figure 1 shows the diffraction patterns of SZN synthesized using various concentrations of salicylic acid (0.1-1.6 mol/L). For $\mathrm{ZnO}$, five intense reflections at 30-60 degrees corresponded to diffractions of 100, 002, 101, 102, and 110 planes, all of which are typical of $\mathrm{ZnO}{ }^{42}$ The diffraction patterns also revealed that the solid had good crystallinity. Intercalation of anions within the interlayer spacing of ZLH would result in an increment in the basal spacing because of displacement of exchangeable interlayer anions. Inclusion of anions in the ZLH interlayers was also reflected by the presence of peaks at a lower $2 \theta$ value, as shown in the diffraction patterns of the SZN nanohybrid. The basal spacing was recorded at $15.78 \AA$, $15.95 \AA, 15.73 \AA$, and $15.98 \AA$ for $0.2 \mathrm{~mol} / \mathrm{L}, 0.4 \mathrm{~mol} / \mathrm{L}$, $0.8 \mathrm{~mol} / \mathrm{L}$, and $1.6 \mathrm{~mol} / \mathrm{L}$ salicylic acid, respectively. Disappearance of the intense $\mathrm{ZnO}$ peaks also indicated that the solid was successfully converted into ZLH. No intercalation took place using $0.1 \mathrm{~mol} / \mathrm{L}$ salicylic acid.

Comparison of the powder X-ray diffraction patterns showed that SZN synthesized using $0.8 \mathrm{~mol} / \mathrm{L}$ salicylic acid was of relatively purer phase. In contrast, the other three nanohybrids still contained $\mathrm{ZnO}$ phase, with SZN synthesized using $0.2 \mathrm{~mol} / \mathrm{L}$ salicylic acid. exhibiting the highest $\mathrm{ZnO}$ intensity. Therefore, the former purer-phase nanohybrid was used for further analysis and labeled as SZN $0.8 \mathrm{~mol} / \mathrm{L}$. Formation of a pure-phase nanohybrid could possibly be hampered by use of nonuniform granular-structured $\mathrm{ZnO}$ particles (Figure 6A). It is postulated that the larger $\mathrm{ZnO}$ particles hindered complete intercalation taking place over a given period of reaction time, thereby resulting in the remainder, ie, unreacted $\mathrm{ZnO}$ phase. ${ }^{43}$

The formation of SZN is believed to have occurred through a dissociation-deposition mechanism. In aqueous conditions, $\mathrm{ZnO}$ hydrolyzed into $\mathrm{Zn}(\mathrm{OH})_{2}$ on the surface of the solid particle. The resulting $\mathrm{Zn}(\mathrm{OH})_{2}$ then dissociated at the solution-solid interface to form $\mathrm{Zn}^{2+}$ species, which then reacted with hydroxyls, salicylate anions, and water in solution to generate the layered SZN nanohybrid compound. ${ }^{44}$

Intercalation of salicylate organic moieties into the interlayer spaces between the metal hydroxide layers resulted in an expansion of the basal spacing, caused by a larger molecular size of salicylate as well as the spatial arrangement of the anions in the intergallery space. Figure 2A shows the threedimensional size of salicylic acid, as estimated by Chemoffice Ultra 2008 software (Cambridge, MA). The long and short axes and molecular thickness of salicylic acid are $8.4 \AA, 6.9 \AA$, and $2.8 \AA$, respectively (Figure $2 \mathrm{~A}$ ). Subtracting the thickness of the ZLH inorganic layer $(4.8 \AA)^{36,45}$ and the zinc tetrahedra $(2.6 \AA \text { each })^{46}$ from the d-spacing of SZN obtained from the
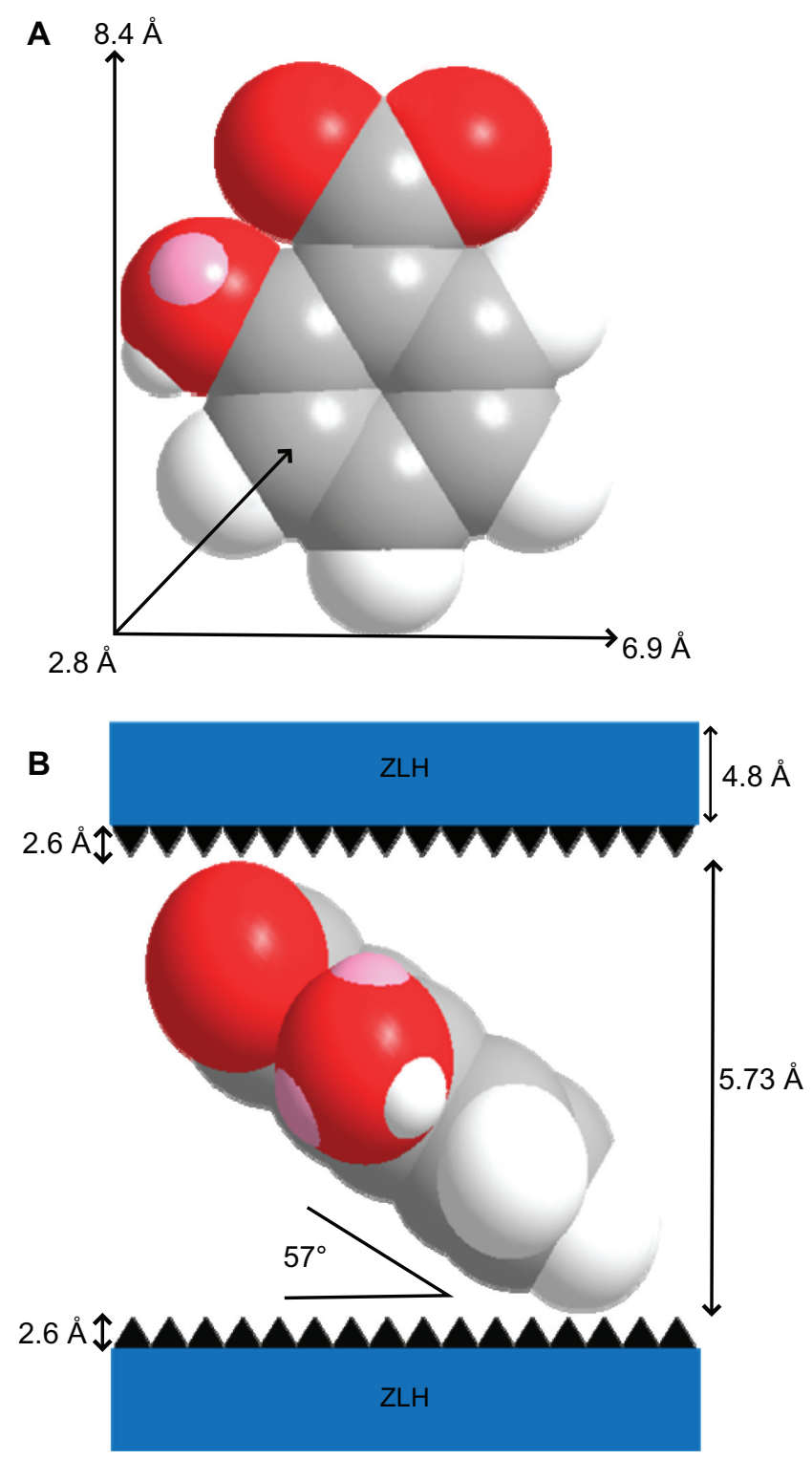

Figure 2 Molecular structure and three-dimensional molecular size of salicylic acid (A) and spatial orientation of salicylate anions in the inorganic interlayers of salicylate-zinc layered hydroxide (ZLH) nanohybrid (B). 
powder X-ray diffraction spectrum ( $15.73 \AA)$, the gallery height available for salicylate occupation was $5.73 \AA$. Because this value was smaller than the dimension of salicylic acid along the $y$ axis and $x$ axis, and bigger than the thickness of two molecules of salicylic acid, the most plausible arrangement is when salicylate anions are arranged as a monolayer with an angle of 57 degrees between the ZLH interlayers, with the carboxylate groups positioned towards the ZLH layers (Figure 2B).

\section{FTIR spectroscopy and elemental analysis}

FTIR spectra for ZnO, salicylic acid, and the SZN $0.8 \mathrm{~mol} / \mathrm{L}$ nanohybrid are shown in Figure 3. The FTIR spectrum for pure $\mathrm{ZnO}$ (Figure 3A) displays a characteristic peak at $373 \mathrm{~cm}^{-1}$, attributable to the vibration of the zinc and oxygen sublattices. ${ }^{47}$ The FTIR spectrum for pure salicylic acid in Figure 3B shows a broad absorption band that spreads from $3229 \mathrm{~cm}^{-1}$ to $2591 \mathrm{~cm}^{-1}$, which can be attributed to the $\mathrm{O}-\mathrm{H}$ stretching vibration. ${ }^{48}$ The band at $1656 \mathrm{~cm}^{-1}$ corresponds to the carbonyl group, while those at $1608 \mathrm{~cm}^{-1}$ and $1439 \mathrm{~cm}^{-1}$ refer to the $\mathrm{C}-\mathrm{C}$ stretching of the aromatic ring. ${ }^{36}$ The bands caused by $\mathrm{C}-\mathrm{O}$ and $\mathrm{O}-\mathrm{H}$ vibration were recorded at $1291 \mathrm{~cm}^{-1}$ and $1236 \mathrm{~cm}^{-1}$, respectively. ${ }^{37}$

The FTIR spectra for the SZN $0.8 \mathrm{~mol} / \mathrm{L}$ nanohybrid in Figure 3C illustrates bands characteristic of pure salicylic acid.

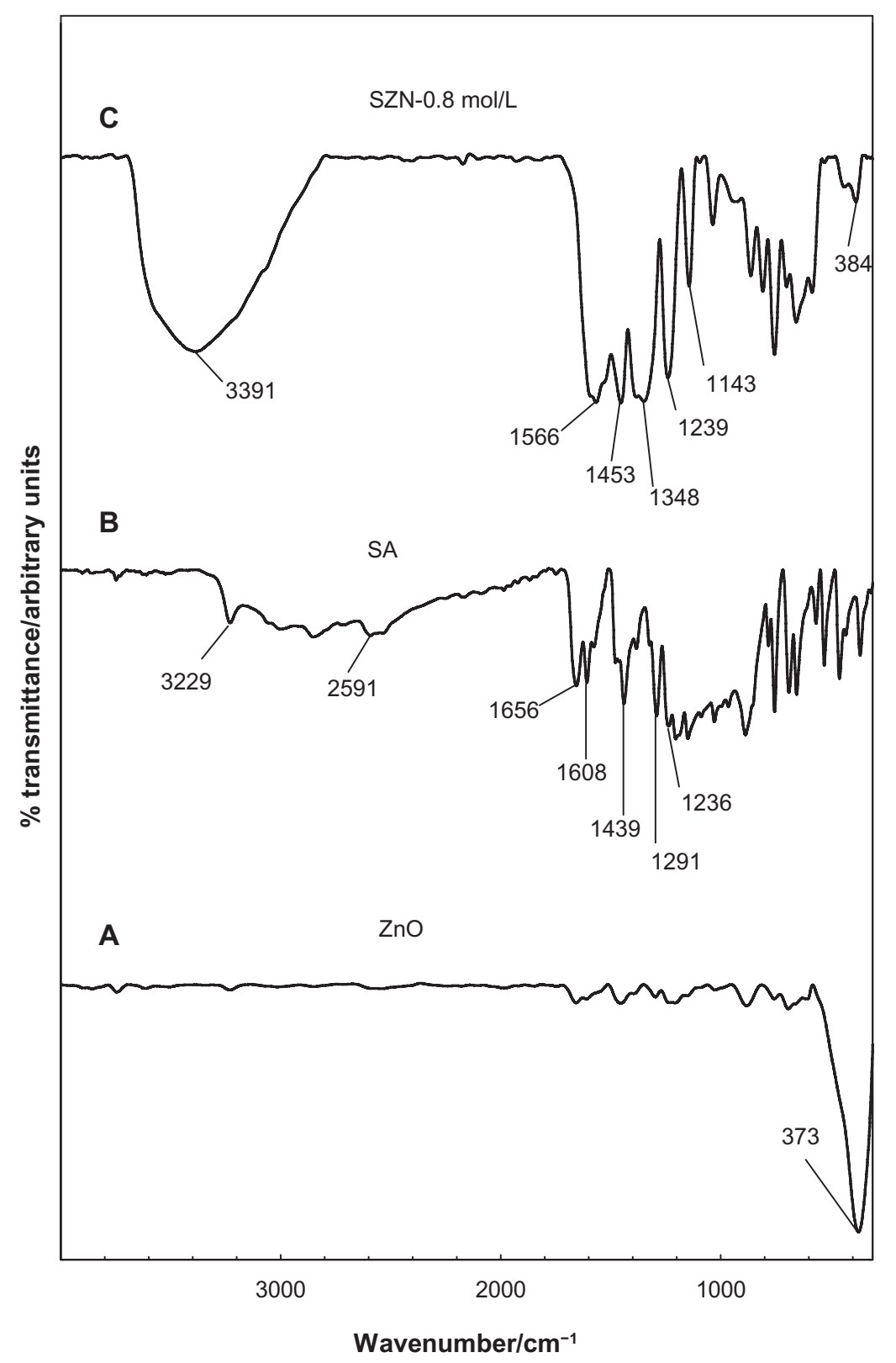

Figure 3 Fourier transform infrared spectra of (A) zinc oxide, (B) salicylic acid, and (C) salicylate-zinc layered hydroxide nanohybrid 0.8 mol/L. 
Table I Physicochemical properties of $\mathrm{ZnO}$ and SZN $0.8 \mathrm{~mol} / \mathrm{L}$

\begin{tabular}{|c|c|c|c|c|c|c|c|c|}
\hline Sample & C (\%) & H (\%) & $\mathbf{N}(\%)$ & $\begin{array}{l}\text { Zn } \\
(\% w / w)\end{array}$ & $\begin{array}{l}{ }^{a} \text { Anion } \\
\text { (\% w/w) }\end{array}$ & $\begin{array}{l}\text { BET surface } \\
\text { area }\left(\mathrm{m}^{2} / \mathrm{g}\right)\end{array}$ & $\begin{array}{l}\text { BJH pore } \\
\text { volume }\left(\mathrm{cm}^{3} / \mathrm{g}\right)\end{array}$ & $\begin{array}{l}\text { BJH pore } \\
\text { diameter }(\AA)\end{array}$ \\
\hline $\mathrm{ZnO}$ & - & - & - & $(80.31)$ & - & 4 & 0.03 & 17 \\
\hline $\mathrm{SZN} 0.8 \mathrm{~mol} / \mathrm{L}$ & 18.04 & 2.09 & - & $56.65^{b}$ & $29.66^{a}$ & 49 & 0.44 & 153 \\
\hline
\end{tabular}

Notes: Values in parentheses are theoretical values; astimated from CHNS analysis; bestimated from inductively coupled plasma analysis.

Abbreviations: ZnO, zinc oxide; SZN, salicylate-zinc layered hydroxide nanohybrid; BJH, Barrett-Joyner-Halenda; BET, Brunauer-Emmett-Teller.

indicating successful intercalation of the guest anions into the ZLH interlayers. However, the band attributable to $\mathrm{C}=\mathrm{O}$ vibration of the acid has vanished because salicylic acid is intercalated in the anionic form. In turn, intense bands developed at $1566 \mathrm{~cm}^{-1}, 1453 \mathrm{~cm}^{-1}$, and $1348 \mathrm{~cm}^{-1}$, which can be attributed to the asymmetric and symmetric carboxylate stretching mode of the salicylate anions. ${ }^{37,49}$ In addition to that, bands recorded at $1239 \mathrm{~cm}^{-1}$ and $1143 \mathrm{~cm}^{-1}$ are attributed to the $\mathrm{C}-\mathrm{C}$ stretch in the aromatic ring, while a band corresponding to $\mathrm{ZnO}$ absorption is detected at $384 \mathrm{~cm}^{-1} .^{24}$ Successful intercalation of salicylate into ZLH was further supported by CHNS analysis, as shown in Table 1. The SZN $0.8 \mathrm{~mol} / \mathrm{L}$ nanohybrid contained $18.04 \%$ carbon $(\mathrm{w} / \mathrm{w})$ and $2.09 \%$ hydrogen $(\mathrm{w} / \mathrm{w})$, and no nitrogen was present in the sample. The loading percentage of salicylate in the nanohybrid was $29.66 \%$ (w/w) and analysis using inductivelycoupled plasma atomic emission spectroscopy showed that SZN $0.8 \mathrm{~mol} / \mathrm{L}$ contained $56.65 \%$ zinc $(\mathrm{w} / \mathrm{w})$.

\section{Thermal analysis}

The TGA-DTG analysis obtained for salicylic acid and SZN $0.8 \mathrm{~mol} / \mathrm{L}$ is shown in Figure 4. The TGA-DTG thermograms for free salicylic acid (Figure 4A) show a single stage of weight loss at a temperature maxima of $142.8^{\circ} \mathrm{C}$, which can be attributed to complete combustion of the pure salicylic acid (99.5\%). Meanwhile, the thermal behavior of the SZN $0.8 \mathrm{~mol} / \mathrm{L}$ nanohybrid shows three stages of weight loss between $40.4^{\circ} \mathrm{C}$ and $491.0^{\circ} \mathrm{C}$ (Figure 4B). The first stage of weight loss between $40.4^{\circ} \mathrm{C}$ and $91.5^{\circ} \mathrm{C}$ is attributed to removal of surface-physisorbed water molecules, ${ }^{41,43}$ with an $8.4 \%$ weight loss. A second band corresponding to intercalated water molecules was not detected during this stage of weight loss, which is further affirmed by the absence of an absorption band at $1600 \mathrm{~cm}^{-1}$ in the FTIR. ${ }^{50}$ This phenomenon was taken into account during the structural modeling exercise described earlier. The other stages of weight loss are characterized by dehydroxylation of the hydroxide layers and decomposition of the organic moieties, ie, salicylate anions. ${ }^{51}$ The stages between $179.8^{\circ} \mathrm{C}$ and $491.0^{\circ} \mathrm{C}$ accounted for a total weight loss of $42.3 \%$. It is worth noting that decomposition of the intercalated salicylate occurred at a notably higher temperature than that of free salicylic acid, indicating that the thermal stability of salicylate in SZN $0.8 \mathrm{~mol} / \mathrm{L}$ is enhanced because of the interaction between salicylate anions and the host, ZLH.

\section{Surface properties and surface morphology}

Figure 5 shows the adsorption-desorption isotherms for $\mathrm{ZnO}$ and $\mathrm{SZN} 0.8 \mathrm{~mol} / \mathrm{L}$. As shown in Figure $5 \mathrm{~A}$, the adsorption-desorption isotherm for $\mathrm{ZnO}$ is categorized as
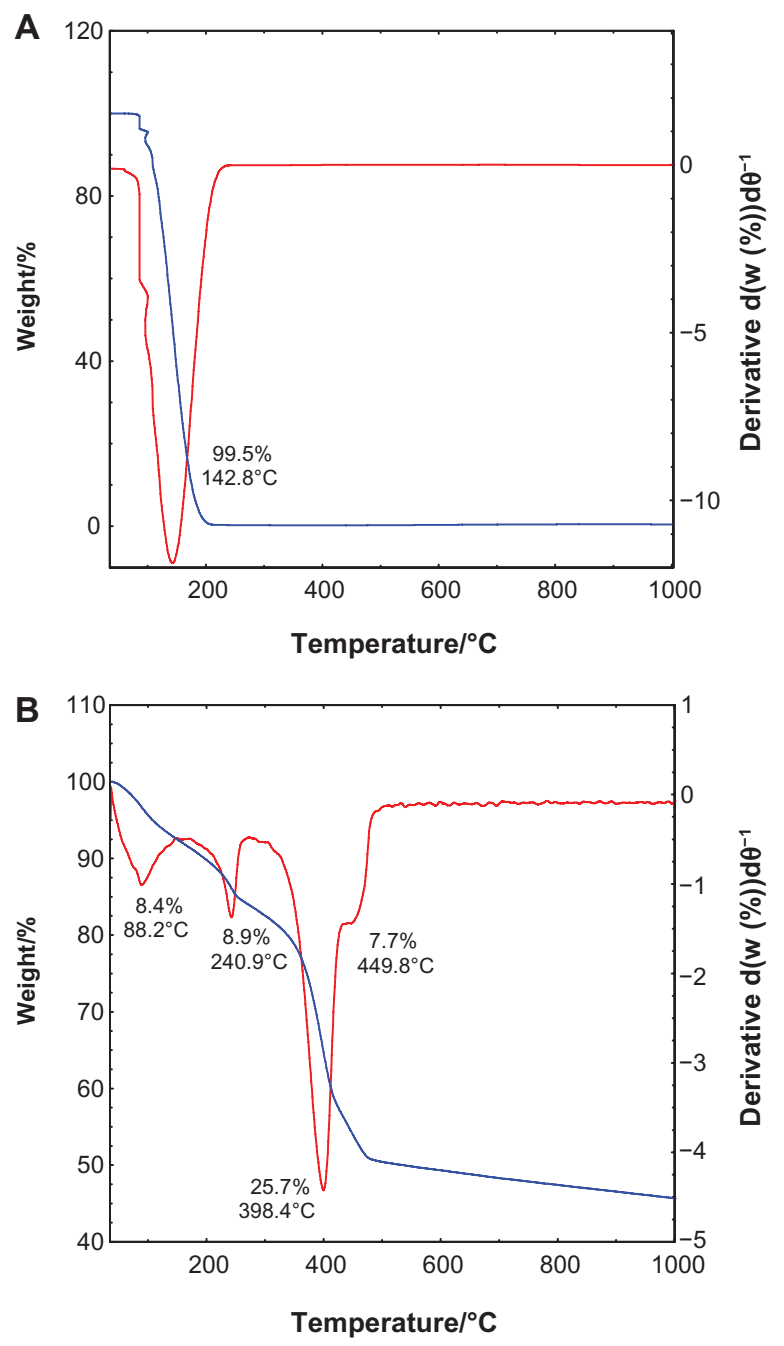

Figure 4 Thermogravimetric and differential thermogravimetric analysis of (A) salicylic acid, and (B) salicylate-zinc layered hydroxide nanohybrid $0.8 \mathrm{~mol} / \mathrm{L}$. 

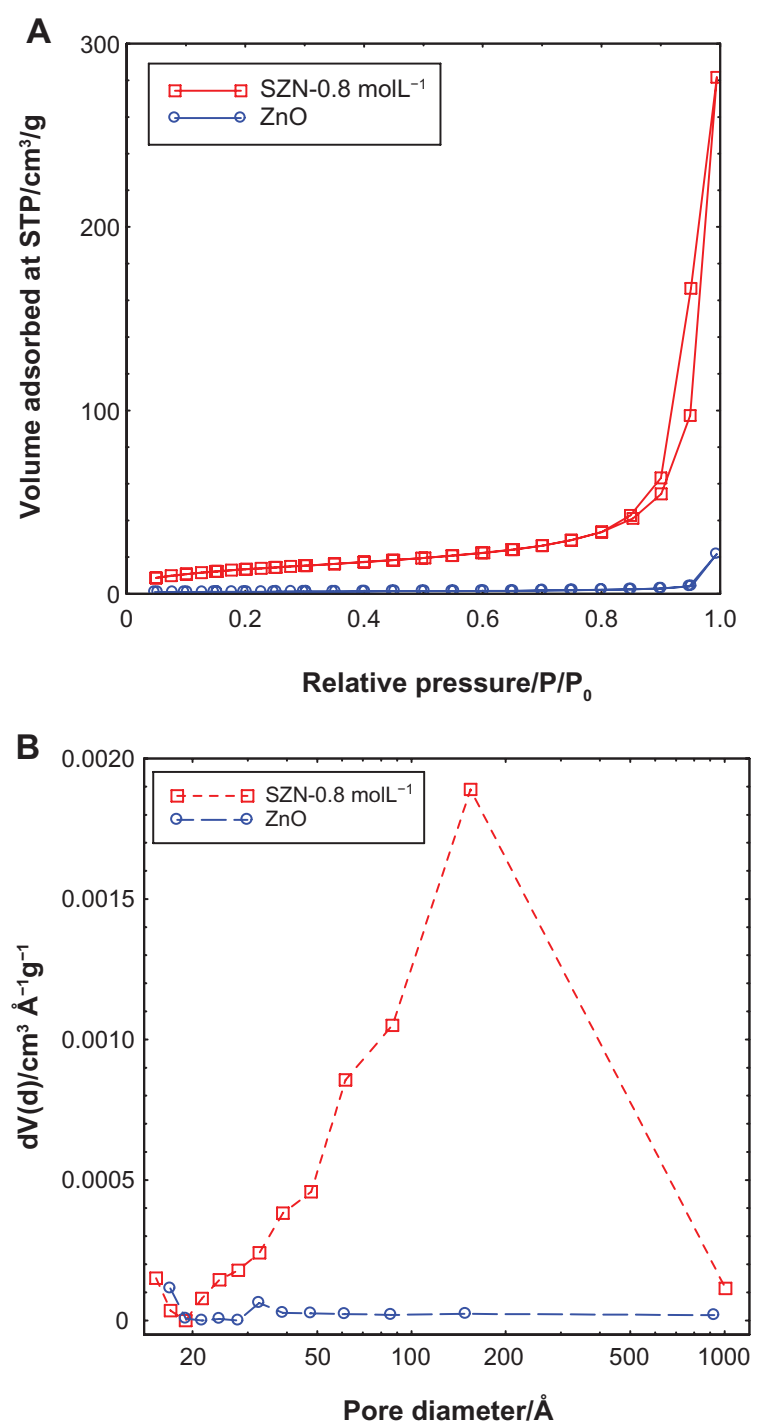

Figure 5 Adsorption-desorption isotherms (A) and Barrett-Joyner-Halenda pore size distribution (B) for $\mathrm{ZnO}$ and $\mathrm{SZN} 0.8 \mathrm{~mol} / \mathrm{L}$.

Abbreviations: $\mathrm{ZnO}$, zinc oxide; $\mathrm{SZN}$, salicylate-zinc layered hydroxide nanohybrid.

type IV by the International Union of Pure and Applied Chemistry classification, which is assigned to materials that have a mesoporous-type structure..$^{52}$ The uptake of adsorbate occurred slowly at low relative pressure in the range of $0.0-0.9$, followed by rapid adsorption from 0.9 onwards until an optimum adsorption of approximately $25 \mathrm{~cm}^{3} / \mathrm{g}$ was achieved. The isotherm of SZN- $0.8 \mathrm{~mol} / \mathrm{L}$ also showed the surface properties of the type IV isotherm..$^{52}$ Adsorption occurred in a gradually increasing manner from the relative pressure of 0.0 to 0.8 . At 0.8 , rapid adsorption ensued, until optimum adsorption took place at a higher relative pressure. The optimum uptake was recorded at $290 \mathrm{~cm}^{3} / \mathrm{g}$, which was 12-fold higher than that of $\mathrm{ZnO}$. The desorption branch of the hysteresis loop for $\mathrm{ZnO}$ was much narrower than that of SZN $0.8 \mathrm{~mol} / \mathrm{L}$, indicating that both materials possessed different pore textures. The surface area of both materials as determined by the Brunauer-Emmett-Teller method is shown in Table 1. As a result of intercalation, the surface area increased from $4 \mathrm{~m}^{2} / \mathrm{g}$ for $\mathrm{ZnO}$ to $49 \mathrm{~m}^{2} / \mathrm{g}$ for $\mathrm{SZN} 0.8 \mathrm{~mol} / \mathrm{L}$.

Figure 5B illustrates the Barrett-Joyner-Halenda pore size distribution plots for $\mathrm{ZnO}$ and $\mathrm{SZN} 0.8 \mathrm{~mol} / \mathrm{L}$. The pore distribution of $\mathrm{ZnO}$ exhibited a peak centered at $32 \AA$, while SZN $0.8 \mathrm{~mol} / \mathrm{L}$ showed an intense peak at approximately $154 \AA$. The pore volume and diameter for $\mathrm{ZnO}$ and $\mathrm{SZN}$ $0.8 \mathrm{~mol} / \mathrm{L}$ are tabulated in Table 1 . The pore volume increased from $0.03 \mathrm{~cm}^{3} / \mathrm{g}$ to $0.44 \mathrm{~cm}^{3} / \mathrm{g}$ for $\mathrm{ZnO}$ and $\mathrm{SZN} 0.8 \mathrm{~mol} / \mathrm{L}$,
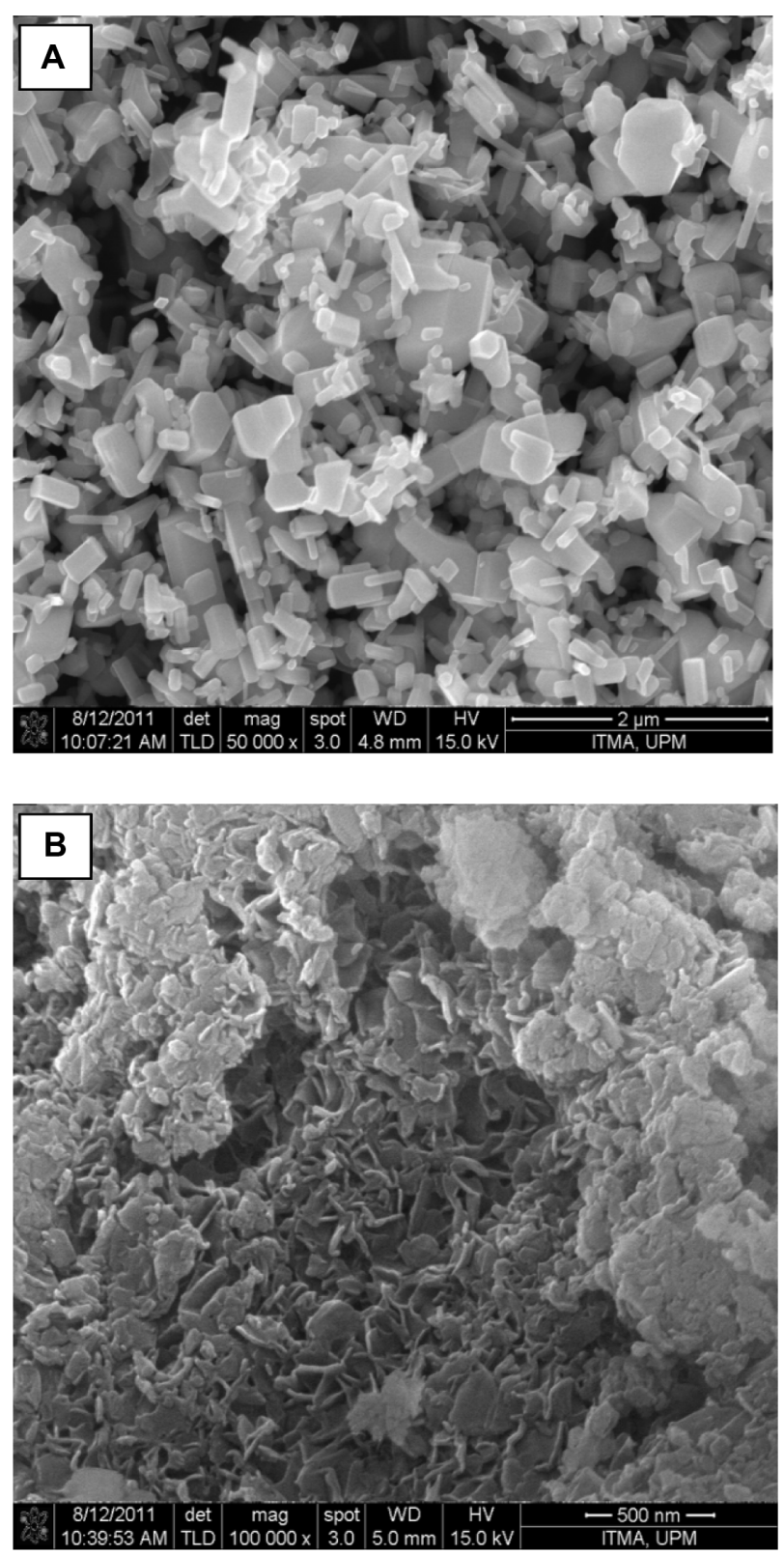

Figure 6 Field emission scanning electron microscopic images of (A) zinc oxide with 50,000 $\times$ magnification and (B) salicylate-zinc layered hydroxide nanohybrid $0.8 \mathrm{~mol} / \mathrm{L}$ with $100,000 \times$ magnification. 
respectively, while the pore diameter increased from $17 \AA$ to $153 \AA$ after salicylate was intercalated into the interlayer spacing of ZLH.

The surface morphology of $\mathrm{ZnO}$ and the SZN $0.8 \mathrm{~mol} / \mathrm{L}$ nanohybrid, examined using field emission scanning electron microscopy, is illustrated in Figure 6. $\mathrm{ZnO}$ was revealed as having a nonuniform granular structure, without any specific shape. The material existed in various sizes and shapes (Figure 6A). After intercalation of salicylate, this structure was transformed into an agglomerate, consisting of curled-up sheet like structures, the particle size of which was markedly reduced in comparison with the starting material, $\mathrm{ZnO}$ (Figure 6B). This shows that inclusion of salicylate into the interlayer spacing of ZLH resulted in a change in the surface morphology, in which an irregular granular structure was converted into more uniform rolled-up sheets.

\section{MTT cytotoxicity test}

The effect of free salicylic acid, $\mathrm{ZnO}$, and the $\mathrm{SZN} 0.8 \mathrm{~mol} / \mathrm{L}$ nanohybrid on the viability of Vero- 3 cells is shown in Figure 7. The cytotoxicity test was performed using an MTT assay, in which the ability of metabolically active cells to convert yellow MTT reagent into purple formazan by chemical reduction of the mitochondrial reductase enzyme is measured.
As shown in Figure 7, viability of the Vero-3 cells decreased as the concentration of the test materials increased. All materials were mildly toxic towards Vero-3 cells, resulting in up to $35 \%$ cell mortality even at the highest dosage used ( $25 \mu \mathrm{g} / \mathrm{mL}$ ). Interestingly, pure $\mathrm{ZnO}$ was found to be the least toxic compared with free salicylic acid and the SZN $0.8 \mathrm{mmol} / \mathrm{L}$ nanohybrid, with $92 \%$ viability calculated using $25 \mu \mathrm{g} / \mathrm{mL} \mathrm{ZnO}$. On the other hand, both free salicylic acid and the SZN $0.8 \mathrm{~mol} / \mathrm{L}$ nanohybrid were found to have a similar effect on the viability of Vero-3 cells. However, at higher concentrations $(12.5 \mu \mathrm{g} / \mathrm{mL}$ and $25 \mu \mathrm{g} / \mathrm{mL})$, the latter was more toxic to the Vero-3 cells, with viability at $80 \%$ and $73 \%$, respectively.

Although all the materials were generally nontoxic, a conclusive effect of concentration on cell viability was regrettably not established in this experiment. The concentrations employed were unable to elicit a more widespread effect on the cells, thereby preventing determination of an $\mathrm{IC}_{50}$ value for each of the test materials. The cells probably needed to be exposed to higher concentrations of the test materials or subjected to a prolonged duration of exposure in order to obtain more comprehensive information on the effect of the test materials on cell viability. Such information is needed before a transfection study entailing investigation

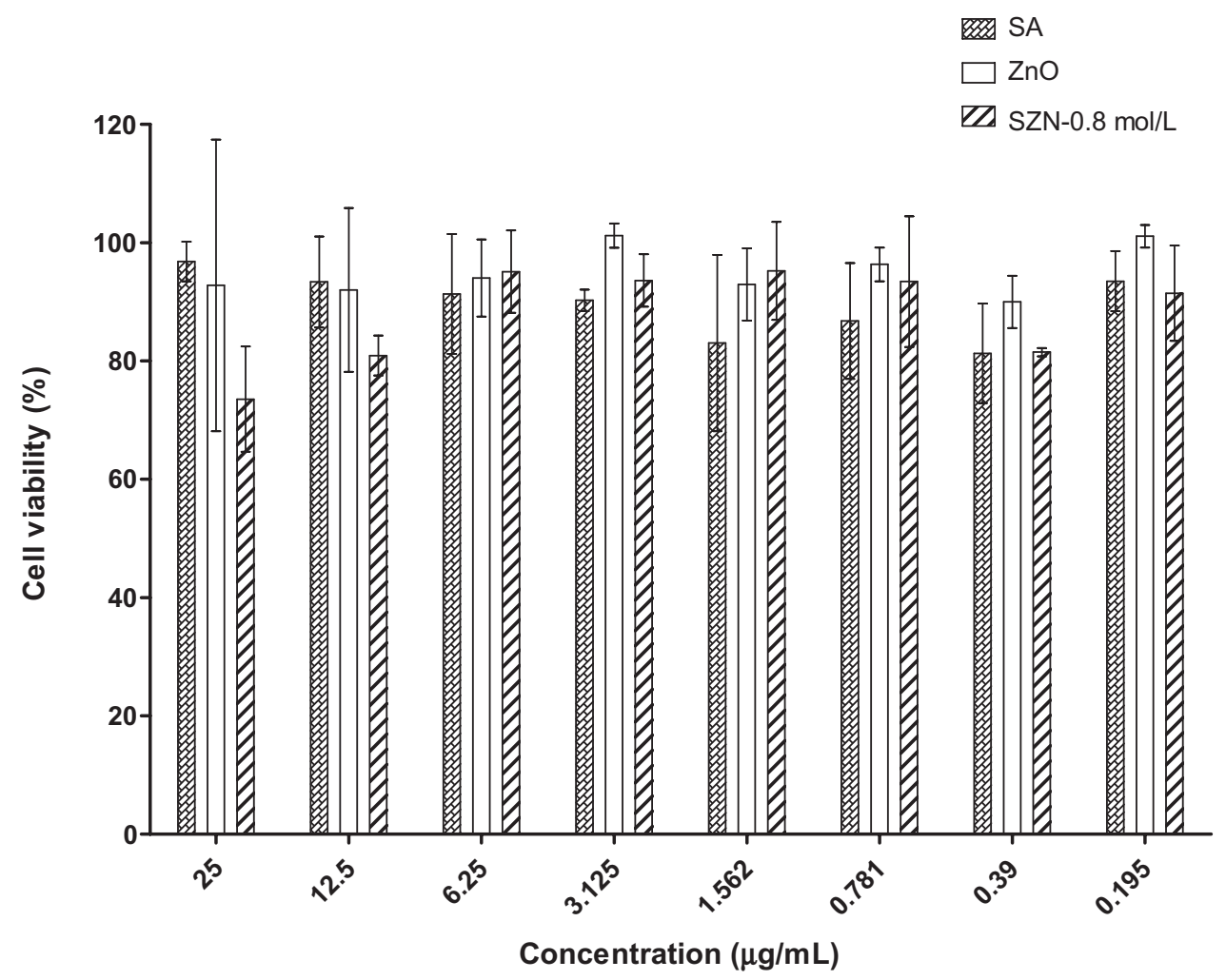

Figure 7 Cytotoxicity analyses of free SA, ZnO, and SZN $0.8 \mathrm{~mol} / \mathrm{L}$ at $25-0.195 \mu \mathrm{g} / \mathrm{mL}$ on Vero-3 cells using the MTT assay. Abbreviations: SA, salicylic acid; SZN, salicylate-zinc layered hydroxide nanohybrid; $\mathrm{ZnO}$, zinc oxide. 
of the effects of the nanohybrid at a molecular level can be carried out.

\section{Conclusion}

A new nanohybrid compound based on salicylate-intercalated ZLH was synthesized via a simple direct reaction of pure $\mathrm{ZnO}$ with salicylic acid solution. The pure-phase nanohybrid was obtained using $0.8 \mathrm{~mol} / \mathrm{L}$ salicylic acid, and the basal spacing was recorded at $15.73 \AA$. FTIR analysis showed that the nanohybrid possesses the absorption characteristics of both $\mathrm{ZnO}$ and free salicylic acid, while elemental analysis showed that the nanohybrid contained $29.66 \%$ (w/w) salicylate. In addition, intercalation of salicylate into the interlayers of ZLH had enhanced thermal stability in comparison with free salicylic acid. It was also found that the Brunauer-Emmett-Teller surface area was increased from $4 \mathrm{~m}^{2} / \mathrm{g}$ to $49 \mathrm{~m}^{2} / \mathrm{g}$ after salicylate was intercalated into ZLH. MTT assay revealed that $\mathrm{ZnO}$ and SZN $0.8 \mathrm{~mol} / \mathrm{L}$ had a mild toxic effect on Vero-3 cells, showing a potential for further use in the development of novel inorganic nanoparticle-based drug delivery systems.

\section{Acknowledgments}

Funding for this research was provided by the Ministry of Science, Technology, and Innovation of Malaysia under a RUGS grant (05-03-10-1035RU). The Universiti Teknologi Malaysia and the Ministry of Higher Education Malaysia are gratefully acknowledged for providing study leave and a scholarship for MR.

\section{Disclosure}

The authors report no conflicts of interest in this work.

\section{References}

1. Trikeriotis M, Ghanotakis DF. Intercalation of hydrophilic and hydrophobic antibiotics in layered double hydroxides. Int J Pharm. 2007;332: 176-184.

2. Faraji AH, Wipf P. Nanoparticles in cellular drug delivery. Bioorg Med Chem. 2009;17:2950-2962.

3. Cho K, Wang X, Nie S, et al. Therapeutic nanoparticles for drug delivery in cancer. Clin Cancer Res. 2008;14:1310-1316.

4. Xu ZP, Zeng QH, Lu GQ, et al. Inorganic nanoparticles as carriers for efficient cellular delivery. Chem Eng Sci. 2006;61:1027-1040.

5. Kidane A, Bhatt PP. Recent advances in small molecule drug delivery. Curr Opin Chem Biol. 2005;9:347-351.

6. Kralj M, Pavelic K. Medicine on a small scale. EMBO Rep. 2003;4: 1008-1012.

7. Gu FX, Karnik R, Wang AZ, et al. Targeted nanoparticles for cancer therapy. Nano Today. 2007;2:14-21.

8. Slowing II, Vivero-Escoto JL, Wu CW, et al. Mesoporous silica nanoparticles as controlled release drug delivery and gene transfection carriers. Adv Drug Deliv Rev. 2008;60:1278-1288.

9. Wu X, Tan Y, Mao H, et al. Toxic effects of iron oxide nanoparticles on human umbilical vein endothelial cells. Int J Nanomedicine. 2010;5: 385-399.
10. Xie J, Chen K, Lee HY, et al. Ultrasmall c(RGDyK)-coated $\mathrm{Fe}_{3} \mathrm{O}_{4}$ nanoparticles and their specific targeting to integrin $\alpha_{v} \beta_{3}$-rich tumor cells. J Am Chem Soc. 2008;130:7542-7543.

11. Lai CY, Trewyn BG, Jeftinija DM, et al. A mesoporous silica nanosphere-based carrier system with chemically removable CdS nanoparticle caps for stimuli-responsive controlled release of neurotransmitters and drug molecules. J Am Chem Soc. 2002;125:4451-4459.

12. Epple M, Kovtun A. Functionalized calcium phosphate nanoparticles for biomedical application. Key Eng Mater. 2010;441:299-305.

13. Cheng $X$, Kuhn L. Chemotherapy drug delivery from calcium phosphate nanoparticles. Int J Nanomedicine. 2007;2:667-674.

14. Shenoy D, Fu W, Li J, et al. Surface functionalization of gold nanoparticles using hetero-bifunctional poly(ethylene glycol) spacer for intracellular tracking and delivery. Int J Nanomedicine. 2006;1:451-472.

15. Madani SY, Naderi N, Dissanayake O, et al. A new era of cancer treatment: carbon nanotubes as drug delivery tools. Int $J$ Nanomedicine. 2011;6:2963-2979.

16. Shao N, Su Y, Hu J, et al. Comparison of 3 generation polyamidoamine dendrimer and generation 4 polypropylene imine dendrimer on drug loading, complex structure, release behavior, and cytotoxicity. Int $J$ Nanomedicine. 2011;6:3361-3372.

17. Hussein Al Ali SH, Al-Qubaisi M, Hussein MZ, et al. Controlled release and angiotensin-converting enzyme inhibition properties of an antihypertensive drug based on a perindopril erbumine-layered double hydroxide nanocomposites. Int J Nanomedicine. 2012;7:2129-2141.

18. Oh JM, Park CB, Choy JH. Intracellular drug delivery of layered double hydroxide nanoparticles. J Nanosci Nanotechnol. 2011;11: $1632-1635$.

19. Choy JH, Park M, Oh JM. Bio-nanohybrids based on layered double hydroxide. Curr Nanosci. 2006;2:275-281.

20. Wen CJ, Zhang LW, Al-Suwayeh SA, et al. Theranostic liposome loaded with quantum dots and apomorphine for brain targeting and bioimaging. Int J Nanomedicine. 2012;7:1599-1611.

21. Ozkan M. Quantum dots and other nanoparticles: what can they offer to drug discovery? Drug Discov Today. 2004;9:1065-1071.

22. Choy JH, Choi SJ, Oh JM, et al. Clay minerals and layered double hydroxides for novel biological applications. Appl Clay Sci. 2007;36: $122-132$.

23. Choy JH, Kwak SY, Park JS, et al. Cellular uptake behavior of $\left[\gamma-{ }^{32} \mathrm{P}\right]$ labeled ATP-LDH nanohybrids. J Mater Chem. 2001;11: 1671-1674.

24. Hussein MZ, Al Ali SH, Zainal Z, Hakim MN. Development of antiproliferative nanohybrid compound with controlled release property using ellagic acid as the active agent. Int J Nanomedicine. 2011;6: 1373-1383.

25. Masarudin MJ, Yusoff K, Abdul Rahim R, Hussein MZ. Successful transfer of plasmid DNA into in vitro cells transfected with an inorganic plasmid-Mg/Al-LDH nanobiocomposite material as a vector for gene expression. Nanotechnology. 2009;20:1-11.

26. Ajat M, Mohd M, Yusoff K, Hussein MZ. Synthesis of glutamatezinc-aluminium-layered double hydroxide nanobiocomposites and cell viability study. Curr Nanosci. 2008;4:391-396.

27. Choy JH, Kwak SY, Jeong YJ, Park JS. Inorganic layered double hydroxides as nonviral vectors. Angew Chem Int Ed Engl. 2000;39: 4041-4045.

28. Auerbach SM, Carrado KA, Dutta PK. Handbook of Layered Materials. New York, NY: Marcel Dekker Inc; 2004.

29. Rives V. Layered Double Hydroxides: Present and Future. New York, NY: Nova Science Publishing Inc; 2001.

30. Meyn M, Beneke K, Lagaly G. Anion-exchange reaction of hydroxy double salts. Inorg Chem. 1993;32:1209-1215.

31. Newman SP, Jones W. Comparative study of some layered hydroxide salts containing exchangeable interlayer anions. J Solid State Chem. 1999;148:26-40.

32. Arizaga GGC, Satyanarayana KG, Wypych F. Layered hydroxide salts: synthesis, properties and potential applications. Solid State Ionics. 2007;178:1143-1162. 
33. Choy JH, Shin J, Lim SY, Oh JM, Oh MH, Oh S. Characterization and stability analysis of $\mathrm{ZnO}$ nanoencapsulated conjugated linoleic acid. J Food Sci. 2010;75:N63-N68.

34. Yang JH, Han YS, Park M, Park T, Hwang SJ, Choy JH. New inorganicbased drug delivery system of indole-3-acetic acid - layered metal hydroxide nanohybrids with controlled release rate. Chem Mater. 2007; 19:2679-2685.

35. Hussein MZ, Ghotbi MY, Yahaya AH, Abd Rahman MZ. Synthesis and characterization of (zinc-layered-gallate) nanohybrid using structural memory effect. Mater Chem Phys. 2009;113:491-496.

36. Hwang SH, Han YS, Choy JH. Intercalation of functional organic molecules with pharmaceutical, cosmeceutical and nutraceutical functions into layered double hydroxides and zinc basic salts. Bull Korean Chem Soc. 2001;22:1019-1022.

37. Mackowiak PA. Brief history of antipyretic therapy. Clin Infect Dis. 2000;31 Suppl 5:S154-S156.

38. Silion M, Hritcu D, Popa MI. Intercalation of salicylic acid into $\mathrm{ZnAl}$ layered double hydroxides by ion-exchange and coprecipitation method. Journal of Optoelectronics and Advanced Materials. 2009;11: 528-534.

39. del Arco M, Gutiérrez S, Martin C, Rives V, Rocha J. Synthesis and characterization of layered double hydroxide $(\mathrm{LDH})$ intercalated with non-steroidal anti-inflammatory drugs (NSAID). J Solid State Chem. 2004;177:3954-3962.

40. Tronto J, Crepaldi EL, Pavan PC, De Paula CC, Valim JB. Organic anions of pharmaceutical interest intercalated in magnesium aluminum LDHs by two different methods. Mol Cryst Liq Cryst. 2001;356: 227-237.

41. Hussein Al Ali SH, Al-Qubaisi M, Hussein MZ, Zainal Z, Hakim, MN. Preparation of hippurate-zinc layered hydroxide nanohybrid and its synergistic effect with tamoxifen on HepG2 cell lines. Int J Nanomedicine. 2011;6:3099-3111.
42. Fernandes DM, Silva R, Winkler Heichenletner AA, et al. Synthesis and characterization of $\mathrm{ZnO}, \mathrm{CuO}$ and a mixed $\mathrm{Zn}$ and $\mathrm{Cu}$ oxide. Mater Chem Phys. 2009;115:110-115.

43. Hussein MZ, Hashim N, Yahaya AH, Zainal Z. Synthesis and characterization of [4-(2,4-dichlorophenoxybutyrate)-zinc layered hydroxide] nanohybrids. Solid State Sciences. 2010;12:770-775.

44. Xingfu Z, Zhaolin H, Yiqun F, Su C, Weiping D, Nanping X. Microspheric organization of multilayered $\mathrm{ZnO}$ nanosheets with hierarchically porous structures. J Phys Chem C. 2008;112: 11722-11728.

45. Misra C, Perrota AJ. Composition and properties of synthetic hydrotalcites. Clays Clay Miner. 1992;40:145-150.

46. Marangoni R, Ramos LP, Wypych F. New multifunctional materials obtained by the intercalation of anionic dyes into layered zinc hydroxide nitrate followed by dispersion into poly(vinyl alcohol) (PVA). J Colloid Interface Sci. 2009;330:303-309.

47. Munõz-Espí A, Chandra A, Wegner G. Crystal perfection in zinc oxide with occluded carboxyl-functionalized latex particles. Cryst Growth Des. 2007;7:1584-1589.

48. Takač MJ-M, Topić DV. FT-IR and NMR spectroscopic studies of salicylic acid derivatives. II. Comparison of 2-hydroxy- and 2,4- and 2,5-dihydroxy derivatives. Acta Pharm. 2004;54:177-191.

49. Hussein MZ, Chan WL. Synthesis of organo-mineral nanohybrid material: indole-2-carboxylate in the lamella of Zn-Al-layered double hydroxide. Mater Chem Phys. 2004;85:427-431.

50. Rocca E, Caillet C, Mesbah A, Francois M, Steinmetz J. Intercalation in zinc-layered hydroxide: zinc hydroxyheptanoate used as protective material on zinc. Chem Mater. 2006;18:6186-6193.

51. Rives V. Characterization of layered double hydroxides and their decomposition products. Mater Chem Phys. 2002;75:19-25.

52. Sing KSW. The use of gas adsorption for the characterization of porous solids. J Colloid Interface Sci. 1989;38:113-124.
International Journal of Nanomedicine

\section{Publish your work in this journal}

The International Journal of Nanomedicine is an international, peerreviewed journal focusing on the application of nanotechnology in diagnostics, therapeutics, and drug delivery systems throughout the biomedical field. This journal is indexed on PubMed Central, MedLine, CAS, SciSearch $\AA$, Current Contents ${ }^{\circledR} /$ Clinical Medicine,

\section{Dovepress}

Journal Citation Reports/Science Edition, EMBase, Scopus and the Elsevier Bibliographic databases. The manuscript management system is completely online and includes a very quick and fair peer-review system, which is all easy to use. Visit http://www.dovepress.com/ testimonials.php to read real quotes from published authors. 